\title{
Quality Teaching: Evaluating Teachers' Professional Code of Conduct and Practices
}

\author{
Muhammad Shakir \\ Ph.D Scholar, Department of Education, The Islamia University of Bahawalpur \\ Email: Shakir.iub@gmail.com \\ Prof. Muhammad Aslam Adeeb \\ Ex-Dean, Faculty of Education, The Islamia University of Bahawalpur \\ Email: aslamadib@yahoo.com \\ Doi:10.5296/ijld.v4i4.6644 \\ URL: http://dx.doi.org/10.5296/ijld.v4i4.6644
}

\begin{abstract}
The study aimed to assess teachers' professional development and code of conduct based on national professional standards in Pakistan. The main objectives of the study were (a) to evaluate teachers' professional development and code of conduct based on national professional standards in Pakistan (b) to categorize teachers' professional competencies based on five levels define in rubrics and (c) to recommend appropriate professional code of conduct and professional standards for global teacher. The population of the study was consisted of all the secondary school teachers of Punjab Province. To conduct the observational survey of this research, a sample of 453 participants from Punjab province was selected to observe the teachers in field directly. The collected data through observational check list was analyzed with the help of software SPSS by using statistical formulas of chi-square, simple mean and percentage. The analysis of various levels shows that $38.4 \%$ teachers occasionally understand how teaching practices can be innovative while only $36.2 \%$ secondary school teachers know the importance of teaching practice. It is concluded that more than half of the teachers were having poor knowledge about professional code of conduct; they did not now even the importance of teaching practice. Majority of the teachers seems incompetent in applying action research during the classroom. Study suggested that there is need to set career development direction through certificates, degrees, and career ladders, linked to compensation adequate with experience and qualifications. These achievements have to be adequately compensated financially, based on achievement and experience.
\end{abstract}

Keywords: Quality teaching, National Standards, Code of conduct, Practice

\section{Introduction}

Teachers in this new environment become fewer instructors and more orchestrators of information, giving children the ability to turn knowledge into wisdom. In order to educate in the $21^{\text {st }}$ century, teachers are desired to cultivate and maintain the student's interest in the material by showing how this knowledge applies in the real world. Their role appears to try to increase their student's curiosity, which helps them to become lifelong learners. There are many skills that children need in order to be successful in the $21^{\text {st }}$ century, the most important skills are: promote effective leadership, quality of teaching, ability to collaborate, critical thinking skills, oral presentation skills, written communication skills, ability to use technology, willingness to examine civic and global issue and chance to learn about new career 
opportunities (Peterson, 2007). In almost all aspects of life significant structural changes are taking place that have direct effect of socio-cultural fabric of society. At the same time education is considered only tool for understanding such changes. It is the responsibility of the educators that they develop such curriculum that helps students to connect with the world and understand the issues and changes that our world is currently facing. Being the foundation of human cognitive development schools in $21^{\text {st }}$ century have become nerve centers, a place for teachers and students to connect with those around them and their community.

Bhargava (2005), Agra (2005) and Sharma (2003) were of the view that the performance of students and quality of education depended upon the quality of teachers. To improve the quality of teachers, teachers must be given a professional status. Being professional, teachers are expected to use the best practices and strategies to meet challenging demand of their career, which involves imparting knowledge and developing essential skills and attitude in the students. The accomplishment of these goals in teaching is determining. They have to use the best of their abilities to achieve these outcomes and use those practices and strategies that have been found more efficient and effective. According to Cruickshank (2009) a good teacher is expected to be committed to his work and would have the ability to take initiatives.

The quality of education depends to great extent on the quality of teacher and quality of teacher without having teaching skills seems impossible. In fact, teacher is considered the top most academic and professional person in the educational pyramid. Without good teachers even the best system of education is found to fail while with good teachers the defects of the system can largely be overcome (Singh, 2007).

The basic purpose of standards is to constitute the 'critical knowledge, skills and attitudes needed to perform a specific role effectively. They explain the primary components of performance rather providing a comprehensive list of responsibilities. Furthermore, they serve to specify what performance or behaviors an institution is particularly looking for. They describe what teachers need to know and do to provide relevant and valuable learning experiences for learners and groups of individuals (Cruickshank, 2009). The extent to which professional standards have been met can be accessed via performance indicators set by the authorities.

Quality assurance requires professional standards of teacher education and an effective mechanism of accreditation of teacher education institutions and programs. The policy and planning Wing of Ministry of Education (MoE) in collaboration with the United Nations Educational Scientific and Cultural Organization (UNESCO) is implementing strengthening teacher education in Pakistan (STEP) with the financial support of the United State Agency for International Development (USAID) under STEP. Professional standards for teachers have been developed in consultation with stakeholder in all provinces. Although, the professional standards are aimed for primary level beginning teachers, these standards can be adapted and used for secondary level teachers and teacher educators. Government of Pakistan has taken an initiative to improve the quality of education through improving the quality of teacher education. It is made an important pillar of the National Educational Policy (National Education Policy, 2010). Standard based development of teachers and other educators is part of a larger international movement of quality assurance in many fields of human endeavor. According to Government of Pakistan (2009) quality assurance in education analyzes with a critical perspective the factors that contribute to educational quality, monitors their presence in the system, and evaluates the impact they have on students learning. A number of studies in the last three decades have pointed out the key issues and problems of teacher education in Pakistan. 


\section{Objectives of research study}

Objectives of the study were (a) to evaluate teachers' professional development and code of conduct based on national professional standards in Pakistan (b) to categorize teachers' professional competencies related to professional codes of conducts based on five levels define in rubrics and (c) to recommend appropriate professional code of conduct and professional standards for global teacher.

\section{Research methodology}

The study was survey type and descriptive in nature. An observation check list sheet was used as a research tool. The population of study was consisted on all the secondary school teachers of government sector including boys and girls situated at urban and rural areas in the province of Punjab. It based on probability sampling methods (multistage cluster sampling) which according to Connolly (2007) serve as the foundation of all statistical tests. Sample was taken from the province of Punjab which was divided into three clusters Northern cluster, Central cluster and Southern cluster. From each cluster two districts were selected as a sample of the study and each was included in the study as the district (strata) were spread geographically and thus, sample was spread, large and ideally representative of the population because according to Best and Kahn (2003) in survey research the sample would be larger enough than experimental researches to represent the population. The districts (strata's) were further divided into urban and rural division and so, the study compared the six districts of Punjab Province. After determining the target population size in selected six districts, sample was calculated with the help of statistical formula at confidence level 95\% (margin error 5\%). The population of secondary school teachers in the whole Province (Punjab) according to School education department, Government of Punjab, is 43200 (http://www.schools.punjab.gov.pk/). To conduct the observational survey of this research, a sample of 453 participants (teachers) were selected to observe them in the field directly.

\section{Research Instrument}

The problem was explored in quantitative term because the teachers' subject knowledge competencies at secondary level could be analyzed better through the observational checklist. The researcher observed the competencies of the respondents in natural setting which they were currently demonstrating, practicing and applying during their classroom teaching. An observation sheet was developed to evaluate the effectiveness of teacher competencies at secondary level. An observational checklist was developed on bases of prescribe levels of teacher accreditation by Policy and Planning wing of Ministry of Education, Pakistan collaboration with UNESCO, is implementing Strengthening Teacher Education Program under the financial support of USAIDs. This Observational check list was used to evaluate the subject knowledge competencies of secondary school teachers based on national professional standard. The parameters of observational check list were taken from the established criteria of each standard, which includes knowledge and understanding, dispositions and performance skills. This observation helped the researcher to collect the empirical evidences of their practices in the classroom teaching. Each standard was further divided according to its pre-determined factors i.e. knowledge and understanding, disposition and performance skills. The data from these observations was used to cross verify the evidences with the quantitative data from the questionnaire field by the research sample. The evidences of observations were reflected their sources of verifications that is discussed in detail in chapter three of this research e.g. teachers dairies, portfolios, lesson plans, individual conferences, peer reviews, classroom observations, , work sheets, journal entries, students' work samples, test scores, research evidences, and parents 'teachers comments etc. 


\section{Macrothink}

\section{Data analysis and results}

Teacher participate as active, responsible members of the professional community, engage in reflecting practices, pursuing opportunities to grow professionally and establish collegial relationships to enhance the teaching and learning process.

\section{Results of the study}

\section{Competencies based analysis of teachers' evaluation}

Following competencies (Professional Code of Conduct and Practice) are prescribed by ministry of education Pakistan in collaboration with UNESCO. Cempetency-1: Teacher knows professional code of conduct, Cempetency-2: Teacher knows how methods of inquiry can be used for continuous learning. Cempetency-3: Teacher understands how teaching practices can be innovative, Cempetency-4: Teacher knows how to develop and maintain personal professional portfolio. Cempetency-5: Teacher is committed to address the needs of students and school/community, Cempetency-6: Teacher is committed to learn the current process for professional reflection. Cempetency-7: Teacher collaborates with colleagues to give and receive help, Cempetency-8: Teacher shares successful professional experiences with others, Cempetency-9: Teacher follows professional code of conduct for self-competency, Cempetency-10: Teacher participates in refresher courses for professional development, Cempetency-11 Teacher involves in school activities for productive learning climate Cempetency-12 Teacher improves teaching practice through action research \& Cempetency-13 Teacher maintains ethical behaviors in teaching, learning and assessment. 
Table 1 Standard: Continuous professional development and code of conduct

\begin{tabular}{|c|c|c|c|c|c|c|c|c|c|c|c|c|}
\hline & \multicolumn{2}{|c|}{ Leevel-0 } & \multicolumn{2}{|c|}{ Level-1 } & \multicolumn{2}{|c|}{ Level-2 } & \multicolumn{2}{|c|}{ Level-3 } & \multicolumn{2}{|c|}{ Level-4 } & \multirow{2}{*}{$x^{2}$} & \multirow{2}{*}{$\begin{array}{l}\text { Sig } \\
.\end{array}$} \\
\hline & $f$ & $\%$ & $f$ & $\%$ & $f$ & $\%$ & $f$ & $\%$ & $f$ & $\%$ & & \\
\hline $\begin{array}{l}\text { C- } \\
1\end{array}$ & 8 & 1.8 & 98 & $\begin{array}{l}21 . \\
6\end{array}$ & $\begin{array}{l}18 \\
6 \\
\end{array}$ & $\begin{array}{l}41 . \\
1\end{array}$ & $\begin{array}{l}14 \\
2 \\
\end{array}$ & $\begin{array}{l}31 . \\
3\end{array}$ & 19 & 4.2 & $\begin{array}{l}262 . \\
11\end{array}$ & $\begin{array}{l}0.0 \\
0 \\
\end{array}$ \\
\hline $\begin{array}{l}\text { C- } \\
2\end{array}$ & 26 & 5.7 & 92 & $\begin{array}{l}20 . \\
3\end{array}$ & $\begin{array}{l}17 \\
7 \\
\end{array}$ & $\begin{array}{l}39 . \\
1\end{array}$ & $\begin{array}{l}13 \\
9 \\
\end{array}$ & $\begin{array}{l}30 . \\
7\end{array}$ & 19 & 4.2 & $\begin{array}{l}210 . \\
91\end{array}$ & $\begin{array}{l}0.0 \\
0 \\
\end{array}$ \\
\hline $\begin{array}{l}\text { C- } \\
3\end{array}$ & 19 & 4.2 & 78 & $\begin{array}{l}17 . \\
2\end{array}$ & $\begin{array}{l}17 \\
4\end{array}$ & $\begin{array}{l}38 . \\
4\end{array}$ & $\begin{array}{l}16 \\
4\end{array}$ & $\begin{array}{l}36 . \\
2\end{array}$ & 18 & 4.0 & $\begin{array}{l}252 . \\
75\end{array}$ & $\begin{array}{l}0.0 \\
0\end{array}$ \\
\hline $\begin{array}{l}\text { C- } \\
4\end{array}$ & 16 & 3.5 & $\begin{array}{l}11 \\
0\end{array}$ & $\begin{array}{l}24 . \\
3\end{array}$ & $\begin{array}{l}12 \\
3\end{array}$ & $\begin{array}{l}27 . \\
2\end{array}$ & $\begin{array}{l}18 \\
4\end{array}$ & $\begin{array}{l}40 . \\
6\end{array}$ & 20 & 4.4 & $\begin{array}{l}228 . \\
46\end{array}$ & $\begin{array}{l}0.0 \\
0\end{array}$ \\
\hline $\begin{array}{l}\text { C- } \\
5\end{array}$ & 19 & 4.2 & 86 & $\begin{array}{l}19 . \\
0\end{array}$ & $\begin{array}{l}12 \\
0\end{array}$ & $\begin{array}{l}26 . \\
5\end{array}$ & $\begin{array}{l}21 \\
3 \\
\end{array}$ & $\begin{array}{l}47 . \\
0\end{array}$ & 15 & 3.3 & $\begin{array}{l}294 . \\
80\end{array}$ & $\begin{array}{l}0.0 \\
0\end{array}$ \\
\hline $\begin{array}{l}\text { C- } \\
6\end{array}$ & 7 & 1.5 & $\begin{array}{l}10 \\
4\end{array}$ & $\begin{array}{l}23 . \\
0\end{array}$ & $\begin{array}{l}15 \\
5\end{array}$ & $\begin{array}{l}34 . \\
2\end{array}$ & $\begin{array}{l}15 \\
5\end{array}$ & $\begin{array}{l}34 . \\
2\end{array}$ & 32 & 7.1 & $\begin{array}{l}208 . \\
57\end{array}$ & $\begin{array}{l}0.0 \\
0\end{array}$ \\
\hline $\begin{array}{l}\text { C- } \\
7\end{array}$ & 15 & 3.3 & 88 & $\begin{array}{l}19 . \\
4\end{array}$ & $\begin{array}{l}15 \\
5\end{array}$ & $\begin{array}{l}34 . \\
2\end{array}$ & $\begin{array}{l}11 \\
6\end{array}$ & $\begin{array}{l}25 . \\
6\end{array}$ & 79 & $\begin{array}{l}17 . \\
4\end{array}$ & $\begin{array}{l}117 . \\
54\end{array}$ & $\begin{array}{l}0.0 \\
0\end{array}$ \\
\hline $\begin{array}{l}\text { C- } \\
8\end{array}$ & 14 & 3.1 & 84 & $\begin{array}{l}18 . \\
5\end{array}$ & $\begin{array}{l}12 \\
6\end{array}$ & $\begin{array}{l}27 . \\
8\end{array}$ & $\begin{array}{l}20 \\
7\end{array}$ & $\begin{array}{l}45 . \\
7\end{array}$ & 22 & 4.9 & $\begin{array}{l}280 . \\
56\end{array}$ & $\begin{array}{l}0.0 \\
0\end{array}$ \\
\hline $\begin{array}{l}\text { C- } \\
9\end{array}$ & 13 & 2.9 & $\begin{array}{l}10 \\
4 \\
\end{array}$ & $\begin{array}{l}23 . \\
0\end{array}$ & $\begin{array}{l}13 \\
2\end{array}$ & $\begin{array}{l}29 . \\
1\end{array}$ & $\begin{array}{l}14 \\
2\end{array}$ & $\begin{array}{l}31 . \\
3\end{array}$ & 62 & $\begin{array}{l}13 . \\
7\end{array}$ & $\begin{array}{l}125 . \\
55\end{array}$ & $\begin{array}{l}0.0 \\
0\end{array}$ \\
\hline $\begin{array}{l}\text { C- } \\
10\end{array}$ & 11 & 2.4 & 62 & $\begin{array}{l}13 . \\
7\end{array}$ & 92 & $\begin{array}{l}20 . \\
3\end{array}$ & $\begin{array}{l}18 \\
7 \\
\end{array}$ & $\begin{array}{l}41 . \\
3\end{array}$ & $\begin{array}{l}10 \\
1\end{array}$ & $\begin{array}{l}22 . \\
3\end{array}$ & $\begin{array}{l}182 . \\
75\end{array}$ & $\begin{array}{l}0.0 \\
0\end{array}$ \\
\hline $\begin{array}{l}\text { C- } \\
11\end{array}$ & 20 & 4.4 & $\begin{array}{l}12 \\
3 \\
\end{array}$ & $\begin{array}{l}27 . \\
2\end{array}$ & $\begin{array}{l}10 \\
2\end{array}$ & $\begin{array}{l}22 . \\
5\end{array}$ & $\begin{array}{l}18 \\
9\end{array}$ & $\begin{array}{l}41 . \\
7\end{array}$ & 19 & 4.2 & $\begin{array}{l}231 . \\
49\end{array}$ & $\begin{array}{l}0.0 \\
0\end{array}$ \\
\hline $\begin{array}{l}\text { C- } \\
12\end{array}$ & $\begin{array}{l}13 \\
9\end{array}$ & $\begin{array}{l}30 . \\
7\end{array}$ & $\begin{array}{l}18 \\
7\end{array}$ & $\begin{array}{l}41 . \\
3\end{array}$ & 98 & $\begin{array}{l}21 . \\
6\end{array}$ & 28 & 6.2 & 1 & 0.2 & $\begin{array}{l}260 . \\
89\end{array}$ & $\begin{array}{l}0.0 \\
0\end{array}$ \\
\hline $\begin{array}{l}\text { C- } \\
13\end{array}$ & 65 & $\begin{array}{l}14 . \\
3\end{array}$ & $\begin{array}{l}18 \\
1 \\
\end{array}$ & $\begin{array}{l}40 . \\
0\end{array}$ & $\begin{array}{l}10 \\
8\end{array}$ & $\begin{array}{l}23 . \\
8\end{array}$ & 81 & $\begin{array}{l}17 . \\
9\end{array}$ & 18 & 4.0 & $\begin{array}{l}159 . \\
96\end{array}$ & $\begin{array}{l}0.0 \\
0 \\
\end{array}$ \\
\hline $\mathbf{T}$ & 29 & 6.4 & $\begin{array}{l}11 \\
8\end{array}$ & $\begin{array}{l}26 . \\
1\end{array}$ & $\begin{array}{l}15 \\
0\end{array}$ & $\begin{array}{l}33 . \\
2\end{array}$ & $\begin{array}{l}13 \\
2\end{array}$ & $\begin{array}{l}29 . \\
2\end{array}$ & 24 & 5.2 & $\begin{array}{l}242 . \\
86\end{array}$ & $\begin{array}{l}\text { 0.0 } \\
\text { 0 }\end{array}$ \\
\hline
\end{tabular}

The knowledge of code of conduct was consider very important for teacher as code of conduct is necessary for all teachers to ensure ethical decision making even in difficult situation. This understanding when measured through different means of verification, a difference in understanding level was found and presented in above table. The analysis of various levels indicated that maximum number of teachers were at level-2 (Developing teacher) that were $(41.1 \%)$ of the total teachers evaluated. This analysis shows that mostly teachers know professional code of conduct. This analysis reveals that most of the teachers $(39.1 \%)$ occasionally know how methods of inquiry can be used for continuous learning. This analysis concluded that a very few teachers were found at the competent level (level 4) of utilizing the knowledge of local tradition. On the basis of above evidence, it is quite clear most of the teachers have poor knowledge of methods of inquiry can be used for continuous learning. Analysis explores the various levels competencies that only $38.4 \%$ evaluated teachers were at level-2 (Developing teacher) that shows inadequate growth toward achieving this competency. The knowledge of the development of professional portfolio was very important for teacher; as personal portfolio helps to take samples of student and teacher work, such as photographs of class projects, lesson plans, student assessments and evidence of professional activities. This understanding when gauged through observation of teaching in classroom, a variation in 
understanding level was found and presented in above table. It is obvious from the data that (40.6\%) teachers know how to develop and maintain personal and professional portfolio. Most of them were considered it daunting work and did not usually develop and maintain portfolio. The knowledge of students and school needs was very important for teacher as students and community needs helps teachers to know the demand of society. It is obvious from the data that (47.0\%) teachers were almost every time committed to address the need of students and school/community but they did not demonstrate competence in their work. $34.2 \%$ and $34.2 \%$ respectively of the total teachers were committed to learn the new pattern of professional development. This analysis further indicates that most of the teachers were at level-2 (Developing teacher) that was (34.2\%) of the total teachers observed. This analysis indicates that most of the teachers they sometimes collaborate with colleagues. Sharing successful professional experiences with others colleagues was important element of continuous professional development and code of conduct. Sharing successful professional experience with others was assumed necessary for teacher as sharing professional experiences helps to understand successful stories of other teachers and try to practice them in classroom teaching. This competency when measured through observation of teaching in classroom. The analysis of various levels indicated that large number of teachers was at level-3 (Proficient teacher) that was $(45.7 \%)$ of the total teachers observed. On the basis of evidence given above, it is concluded that a few teachers were found at competent level (level 4) that usually share successful professional experiences. Further data clarifies that most of the teachers $31.3 \%$ practice professional code of conduct for self-competency but they did meet the desire level of competency. It is quite clear from the above data that most of the teachers demonstrated inadequate growth toward achieving this competency during classroom observation. The refresher courses for professional development was assumed necessary for teacher as refresher courses helps to aware about the new trends related to profession.. This analysis indicates that most of the teachers $41.3 \%$ almost every time prefer and participate in refresher courses for professional development to enhance their professional skills. Empirically, it is evident that number teachers were found at competent level (level 4) that teachers taking part in refresher courses. It shows government is providing them opportunities to participate in refresher courses. Hence, it can be said that few of the teachers did not take interest to take part in refresher courses. Engaging someone in school activities for productive learning climate was very important for teacher as it helps the teacher to make entire school productive learning climate through the participation of collegial activities. This understanding when measured through observation of teaching in classroom, a difference in understanding level was found and presented in above table. The analysis of various levels indicated that great number of teachers was at level-3 (Proficient teacher) that was (41.7\%) of the total teachers observed. According to the analysis of various levels indicated that maximum number of teachers was found at level-1 (Emerging teacher) that was $(41.3 \%)$ of the total teachers observed. This analysis indicates that most of teachers almost never solve classroom problems through action research while $(30.7 \%)$ teachers were found at level-0 (Not demonstrated teacher) that never practice action research to improve teaching. The sustainability of ethical behavior in teaching was assumed necessary for teacher as ethical behavior helps to inculcate life skills among students. This understanding when gauged through observation of teaching in classroom, a variation in understanding level was found. The present analysis indicated that maximum number of teachers was found at level-1 (Emerging teacher) that was (40.0\%) of the total teachers observed. This analysis indicates that mostly the teachers almost never try to inculcate social values in teaching. On the basis of above evidences, very limited teachers were found at competent level (level 4) of practicing ethical behavior in teaching, learning and assessment. 


\section{Discussion}

Continuous professional development of teachers is a process of continually progressing and refining your character and qualities. A teacher having professionally developed always demonstrates competency in teaching. The results of the study indicate the majority of the teachers have poor knowledge of professional code of conduct. A significant number of teachers understand how teaching practices can be innovative. This study further discussed that secondary school teachers know how to develop and maintain personal and professional portfolios but they were not practicing it properly. It seems to support Tahseen (2010) mentions that secondary school teachers usually considered it boring activity to maintain personal professional portfolios. When principals were asked about this practice they also verify and commented that they feel burden to update personal and professional portfolios. Teachers were found visionary and mostly they share their professional experiences with other teachers. Focus group discussion disclosed interesting results that most of the teachers participate in workshop as a source of getting honorarium and certificates. Practicing action research during classroom teaching always remained a major concern of secondary school teachers. Cruickshank et, al (2009) says that classroom teachers engage in action research to help them better understand their teaching and to solve problems related to learning. Overall results and mean score (3.11) of standard-9 identified that most of teachers demonstrated poor performance and were found at emergent level of teachers.

\section{Conclusions}

In the light of results and discussion of the study it was concluded that continuous professional development and code of conduct was very important for teachers. Professionally developed teachers always demonstrated competency in their teaching. A teacher should know professional code of conduct for effective learning. During classroom observation teachers knowledge about professional code of conduct was remain question mark. More than half of the teachers teaching at secondary schools of Punjab province were having poor knowledge about professional code of conduct. More than half of the teachers occasionally understand the important of teaching practice. Most of the teachers know how to develop and maintain personal and professional portfolio but did not practice properly. On the basis of evidences given above in results it was concluded that more than half of the teachers sometimes collaborates to give and receive help while the comments of colleagues favored that almost half of the teachers almost every time share successful professional experience with others. In the light of the comments of teachers it was concluded that almost half of the teachers almost every time participated in professional development workshops while a significance numbers of teachers always participated professional development workshops. Majority of the teachers seems incompetent in using action research during the classroom. Overall it was concluded that the result in standard-9 continuous professional development and code of conduct concluded that most of the teachers know the professional code of conduct they categorized as emerging teacher.

\section{Recommendations}

Recognizing the importance of teacher professional development and code of conduct there is an urgent need to examine current professional policies for teachers at the entrance level and programs for training of teachers on job or during the service. It is suggested that standards for professional development of the teachers should be carefully observed. There is need to set career development directions through certificates, degrees, and career ladders, linked to compensation commensurate with experience and qualifications. These achievements have to be adequately compensated financially, based on achievement and experience. Further teacher should be given opportunities to participate in national and international conferences, 
seminars. Symposiums, workshops and trainings so that they may learn professional codes for teacher development.

\section{References}

Agra, (2005). Teachers in $21^{\text {st }}$ Century. New Delhi, India: Published by Prentice Hall of India. Best, J.W., \& Kahn, J.V. (2006). Research in Education. (9 ${ }^{\text {th }}$ ed.) India: Pearson Education, Inc. Bhargava, M. \& Bharagava, P. (2005). Appraisal of Modern Education. Published by Prentice Hall of India, New Delhi, India.

Cruickshank et al. (2009). The Act of Teaching. Published by McGraw Hill companies, New York, USA.

Government of Pakistan, (2009). National Professional Standards for Teachers in Pakistan, Policy of Planning wining, Ministry of Education, Islamabad, Pakistan.

Government of Pakistan. (2002). Facts and Figures. Ministry of Education E .F. Wing, Islamabad, Pakistan. pp. 18-9.

Peterson, D. K. (2007). Effective Teacher Evaluation: A practical guide for principals, Corwin Press.INC, California.

Siddiqui, S. (2007). Rethinking Education in Pakistan ; Perspectives, Practice, \& Possibilities. Karachi; Paramount Publishing Enterprise.

Siddiqui, M.A. (1991). In-service teacher education New Delhi: Ashish Publicationhouse 8/81. Punjabi Bagh.

Sinha S. (2007). Teaching Competencies in Emerging Indian Society. Adhyayan Publisher \& Distributors, New Dehli-110002, India.

Singh, M.S. (2007). Teacher Education in Dilemma. Adhyayan Publishers \& Distributors, New Delhi.

Singh, R.P. (2004). Modernization of Teacher Education. New Delhi: Common Wealth GaliMurariLal, Ansari Road Darya Ganj.

Srivastava, S. (2007). Competency Based Teacher Education. Adhyayan Publisher \& Distributors, New Delhi, India.

UNESCO. (2008). Quality of Primary Education in Pakistan. UNESCO Office. 